\title{
The potential of current european light duty CNG-fuelled vehicles to meet Euro 6 requirements
}

\begin{abstract}
Natural gas is one of the most promising alternative fuels to meet the new stringent Euro 6 emissions regulations in the European Union, as well as the planned $\mathrm{CO}_{2}$ emissions reductions. For spark-ignition (SI) engines, bi-fuel fuelling equipment is widely available and engine conversion technology for European automobiles is well established, thereby facilitating usage of $C N G$ in this engine type.

This study investigates the implications of natural gas fuelling of a passenger car featuring a spark-ignition engine regarding the possibility of meeting Euro 6 emissions limits for gaseous pollutants. This paper presents an analysis of $\mathrm{CO}, \mathrm{THC}, \mathrm{NMHC}, \mathrm{NO}_{x}$ and $\mathrm{CO}_{2}$ emissions during testing of a vehicle on a chassis dynamometer, fuelled with CNG, in the context of the new Euro 6 emissions requirements. The analyses were performed on a Euro 5 bi-fuel vehicles with an SI engine equipped with an MPI feeding system operating in closed-loop control, a typical three-way-catalyst, and a heated oxygen sensor. The vehicles had been adapted by their manufacturer for fuelling with CNG by using additional special equipment mounted onto the existing petrol fuelling system. The vehicles tested featured a multipoint gas injection system latest generation.

The tests subject to the analyses presented here were performed in the Engine Research Department of BOSMAL Automotive Research and Development Institute Ltd in Bielsko-Biala, Poland, within a research programme investigating the influence of alternative fuels on exhaust emissions from automotive vehicles with spark-ignition and compressionignition engines.
\end{abstract}

Key words: light duty vehicle, alternative fuels, CNG, SI engine, exhaust emissions, Euro 6

\section{Możliwości spełnienia norm emisji Euro 6 przez obecnie produkowane europejskie lekkie pojazdy samochodowe zasilane gazem ziemnym}

Gaz ziemny jest jednym z najbardziej obiecujacych paliw alternatywnych $w$ aspekcie spetnienia wymagań nowych, obniżonych limitów emisji związków szkodliwych spalin w planowanych przepisach Euro 6 w Unii Europejskiej i jednocześnie umożliwiającym planowana redukcję emisji $\mathrm{CO}_{2}$ przez pojazdy samochodowe. Dla silników z zapłonem iskrowym rozwiazania konstrukcyjne do zasilania silnika dwoma rodzajami paliwa: benzyna i gazem ziemnym sa dobrze znane. Producenci uktadów zasilania silnika gazem dysponują obecnie rozwiąaniami gotowymi do zastosowania w nowoczesnych silnikach samochodowych.

Tematem niniejszego artykutu jest analiza emisji $\mathrm{CO}$, THC, NMHC, $\mathrm{NO}_{x}$ i $\mathrm{CO}_{2}$ podczas testów pojazdu zasilanego gazem ziemnym CNG na hamowni podwoziowej w aspekcie spetnienia nowych standardów emisji spalin Euro 6. Próby przeprowadzano z wykorzystaniem pojazdów spetniajacych limity normy Euro 5, wyposażonych w silniki o zapłonie iskrowym $z$ wielopunktowym wtryskiem paliwa sterowanym ze sprzężeniem zwrotnym na podstawie sygnału $z$ sondy lambda, typowym trzyfunkcyjnym reaktorem katalitycznym i podgrzewanym czujnikiem zawartości tlenu w spalinach. Samochody używane w badaniach byly dostosowane przez producenta do zasilania gazem ziemnym CNG przez użycie dodatkowego osprzętu, oprócz istniejącego systemu zasilania benzyną. Badane samochody wyposażone byty w system wielopunktowego wtrysku gazu ziemnego najnowszej generacji.

Badania i analizy przeprowadzono w Zakładzie Badań Silników Instytutu Badań i Rozwoju Motoryzacji BOSMAL w Bielsku-Białej, w ramach programu badań majacych na celu określenie wplywu zastosowania paliw alternatywnych na możliwość obniżenia poziomu emisji zwiąków szkodliwych spalin z pojazdów samochodowych z silnikami o zapłonie iskrowym (ZI) i samoczynnym (ZS).

Słowa kluczowe: lekkie pojazdy samochodowe, paliwa alternatywne, gaz ziemny, CNG, silnik samochodowy, emisja spalin, Euro 6

\section{Introduction}

Air pollution and the necessity of reducing greenhouse gas emissions are becoming the main global problems with population growth and the resulting increase in demand for transportation. The use of alternative fuels (biodiesel, gasoline-alcohol blends, CNG, LPG) in vehicular powertrains has grown in recent years in European Union countries, the United States, Japan, India, Brazil and many other countries,

\section{Wstęp}

W związku z wzrastającą liczbą ludności i stale zwiększającym się zapotrzebowaniem na środki transportu, zanieczyszczenie powietrza szkodliwymi składnikami spalin silnikowych i konieczność obniżenia emisji gazów cieplarnianych stają się coraz większym problemem w skali światowej. Zwiększenie ilości wykorzystywanych paliw alternatywnych (biodiesel, mieszanki etanolu z benzyną, $\mathrm{CNG}$ 
due to finite fossil fuel resources and the necessity of a reduction in anthropogenic $\mathrm{CO}_{2}$ emissions. The main drivers that have an influence on future personal transportation are $[3,5,12,14,21]$ :

- climate change as the biggest environmental challenge strong action dedicated for the contribution of the transport sector to the reduction of greenhouse gas emissions - global $\mathrm{CO}_{2}$ legislation targets for new passenger cars,

- emissions regulatory development at European, US and Asian level - regulation as an incentive for innovation (examples: Euro 5+ and Euro 6, US Tier 2 \& 3, CARB LEV II \& III, Japanese Long Term Regulations, new hydrogen vehicles regulations, etc.),

- automotive growth opportunities in aspects of global energy consumption,

- powertrain development from a fuel perspective - alternative fuel resources and blending strategies.

New European requirements regarding vehicle emissions for passenger cars (PC) and light commercial vehicles (LCV) were introduced in 2009 for type approval (TA) and 2011 for all new types (ANT), specified as Euro 5, with further requirements (Euro 6) planned for 2014/2015 (Fig. 1). For PC and LCV, the key elements for Euro 5 and Euro 6 are as follows [5, 14]:

1. Reduction in tailpipe emission limits in NEDC cycle (the same as with the Euro 3 \& Euro 4 standards):

a) $20 \% \mathrm{NO}_{\mathrm{x}}$ emission reduction (diesel $\mathrm{NO}_{\mathrm{x}}$ limit is closer to gasoline $\mathrm{NO}_{\mathrm{x}}$ ),

b) $80 \% \mathrm{PM}$ emission reduction (mass + particle number by the widespread introduction of DPFs),

c) application of particulate mass measurement for gasoline DI engines and nanoparticle number measurement for diesel engines in Euro 5 and gasoline DI engines in Euro 6,

d) application of measurement of NMHC in addition to THC emissions for gasoline engines,

e) the same limits for gaseous pollutants from gasoline engines in Euro 5 and Euro 6.

2. Vehicle durability increases from 80,000 to $160,000 \mathrm{~km}$ for Euro 5 and further to 200,000 km for Euro 6 .

3. Consideration of the effect on $\mathrm{CO}_{2}$ emissions - the achievement of the 2008 commitment and introduction of fleet average limit for $\mathrm{CO}_{2}$ emissions.

4. Introduction of cleaner fuels for improved emission control technology.

In the last few years several institutions and organizations have presented predictions for world energy demand. According to these publications, world energy demand will increase from 2005 to 2030 by $50 \div 60$ per cent. Fossil fuels will remain the main energy sources for transportation; however, sufficiency of oil supply might become a problematic issue [2, 3, 22].

Currently, natural gas (NG) is the best alternative for oil as an energy source. $\mathrm{CNG}$ is economically sustainable compared to fossil oil and it is available with a more favourable geopolitical distribution. Due to its high knock resistance (RON 130) NG is a very good fuel for turbocharged SI engines. i LPG) w jednostkach napędowych pojazdów występuje w krajach Unii Europejskiej, Stanach Zjednoczonych, Japonii, Indiach, Brazylii i wielu innych państwach w związku z wyczerpywaniem się zapasów paliw kopalnych i potrzebą obniżenia antropogenicznej emisji $\mathrm{CO}_{2}$. Głównymi czynnikami, które wpływają na indywidualny transport przyszłości są $[3,5,12,14,21]$ :

- zmiany klimatyczne jako największe wyzwanie środowiskowe; zdecydowane działanie dotyczące udziału sektora transportowego w procesie zmniejszenia emisji gazów cieplarnianych ; ogólnoświatowe ustawodawstwo dotyczące redukcji poziomu emisji $\mathrm{CO}_{2}$ przez samochody osobowe i ciężarowe,

- rozwój przepisów prawnych dotyczących emisji związków szkodliwych spalin na poziomie europejskim, amerykańskim i azjatyckim; limity emisji bodźcem dla innowacyjności (np.: Euro 5+ i 6, US Tier 2 i 3, LEV 2 i 3, Japan 2009 Long Term Regulation, nowe wytyczne dla pojazdów wodorowych itd.),

- szansa rozwoju motoryzacji w aspekcie globalnej konsumpcji energii,

- rozwój silników pod kątem zastosowania nowych typów paliw; strategia alternatywnych źródeł paliw i ich mieszanin z paliwami konwencjonalnymi.

Nowe europejskie wymagania dotyczące emisji związków szkodliwych spalin dla samochodów osobowych i lekkich pojazdów użytkowych określane jako Euro 5 zostały wprowadzone w 2009 r. dla nowo homologowanych pojazdów i od 2011 r. dla wszystkich nowych pojazdów, a kolejne zmiany wymagań (określane jako Euro 6) planowane są do wprowadzenia w latach 2014-2015 (rys. 1). Dla samochodów osobowych i lekkich pojazdów dostawczych kluczowe elementy norm Euro 5 i Euro 6 są następujące:

1.Zmniejszenie limitów emisji z układu wylotowego pojazdu podczas cyklu jezdnego NEDC (takie same jak w normie Euro 3/4):

a) zmniejszenie o $20 \%$ emisji $\mathrm{NO}_{\mathrm{x}}$ (limity dotyczące silników ZS są zbliżone do limitów emisji $\mathrm{NO}_{\mathrm{x}}$ silników ZI),

b) zmniejszenie o $80 \%$ emisji PM (masowej + liczby cząstek stałych), szerokie wprowadzenie filtrów cząstek stałych (DPF),

c) wprowadzenie obowiązku pomiaru masy cząstek dla silników benzynowych $\mathrm{z}$ bezpośrednim wtryskiem paliwa i liczby nanocząstek stałych w spalinach dla silników ZS w Euro 5 i silników ZI z bezpośrednim wtryskiem benzyny od Euro 6,

d) dodanie obowiązku pomiaru NMHC do pomiarów emisji THC,

e) limity gazowych związków szkodliwych są takie same w Euro 6 jak w Euro 5.

2. Wzrost trwałości pojazdu w zakresie spełniania norm emisji z 80000 do $160000 \mathrm{~km}$ dla normy Euro 5 i dalej do $200000 \mathrm{~km}$ dla normy Euro 6.

3. Rozważenie wpływu na globalną emisję $\mathrm{CO}_{2}$ - osiągnięcie zobowiązania redukcji tej emisji z 2008 r. i wprowadzenie średniego limitu emisji $\mathrm{CO}_{2}$ dla floty pojazdów. 
The European Commission has accepted the target of 20 per cent replacement of conventional fuels by alternative fuels (biofuels, CNG, hydrogen), of which up to 10 per cent $\mathrm{CNG}$, in the road transportation sector by 2020 (Fig. 2) $[11,12,13]$.

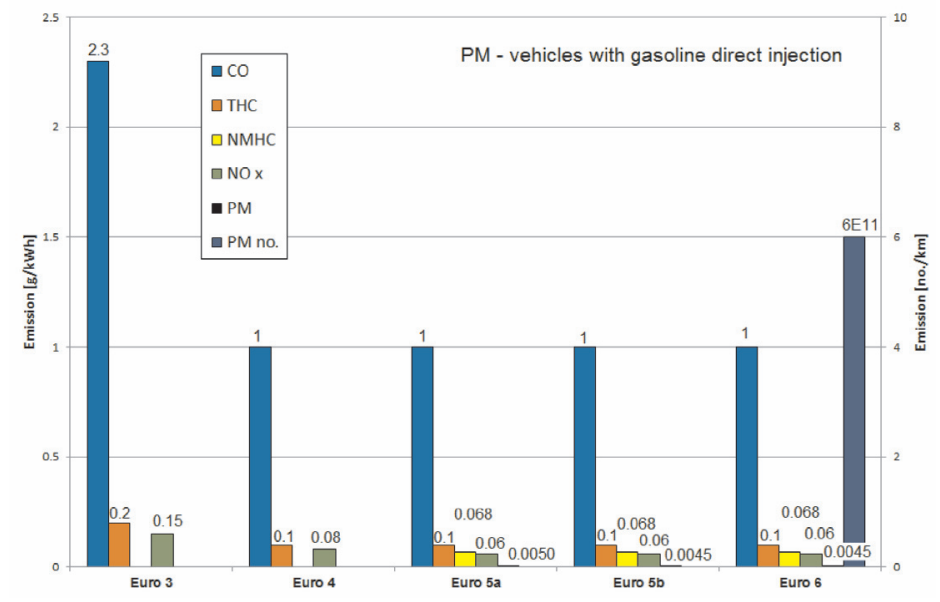

Fig. 1. Progress in European emission regulations for passenger cars fitted with spark ignition engines

Rys. 1. Postęp w europejskich przepisach dotyczacych emisji związków szkodliwych spalin dla samochodów osobowych z silnikami o zapłonie iskrowym

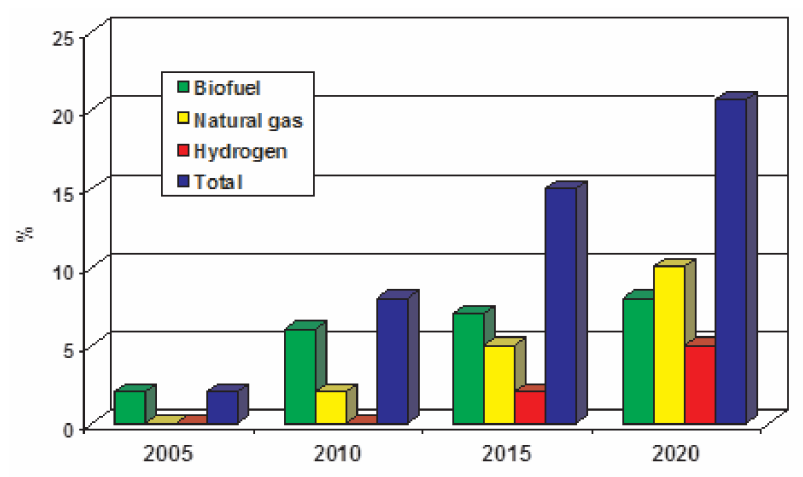

Fig. 2. European Union suggested scenario for alternative fuel use by 2020 according to Directives 2003/30/EC and 2003/96/EC

Rys. 2. Sugerowany przez Unię Europejska scenariusz wykorzystania paliw alternatywnych do roku 2020 wedlug Dyrektyw 2003/30/EC i 2003/96/EC

Natural gas is widely used in the refining industry of liquid transportation fuels. It is seen as the bridge to a future hydrogen-based society. The locations of the main global natural gas reserves are shown in Fig. 3.

Natural gas vehicle numbers are growing and reached a figure of about 6.5 million in 2007. The average growth since 2000 has been 30 per cent. The largest markets for CNG vehicles are Argentina, Pakistan and Brazil. The majority of this fleet consists of simple after-market conversions, which would not meet European and North American emissions standards. In 2007 there were around 800,000 CNG vehicles in Europe (around 400,000 in Italy, 55,000 in Germany, 13,000 Sweden and about 10,000 in France);
4. Wprowadzenie czystszych paliw celem poprawienia skuteczności działania układów katalitycznego obniżania emisji.

W ostatnich latach kilka instytucji i organizacji międzynarodowych przedstawiło $\mathrm{w}$ publikacjach przewidywane światowe zapotrzebowanie na energię. Zgodnie z tymi publikacjami światowe zapotrzebowanie na energię wzrośnie w latach 2005-2030 o około $50 \div 60 \%$. Paliwa kopalne pozostaną głównym źródłem energi dla transportu; jednakże dostateczne ilości zapasów ropy naftowej mogą stać się problemem w tym czasie [2, 3, 14].

Obecnie gaz ziemny jest najlepszą alternatywą dla ropy naftowej jako źródła energii. CNG jest ekonomicznie lepiej ocenianym paliwem niż ropa naftowa $\mathrm{i}$ jest dostępny w bardziej korzystnym podziale geopolitycznym. Dzięki wysokiej odporności na spalanie stukowe (RON 130) gaz ziemny jest bardzo dobrym paliwem dla turbodoładowanych silników ZI. Komisja Europejska w 2003 r. zaakceptowała jako cel dla transportu zastąpienie konwencjonalnych paliw w $20 \%$ przez paliwa alternatywne (biopaliwa, CNG, wodór), z czego udział CNG ma wynosić 10\%, w sektorze transport drogowego do 2020 r. (rys. 2) [11, $12,13]$. Gaz ziemny jest szeroko stosowany w przemyśle rafineryjnym ciekłych paliw transportowych. Postrzegany jest jako pomost do transportu dla przyszłych społeczeństw, oparty w przyszłości na używaniu wodoru jako paliwa. Główne światowe zasoby gazu ziemnego przedstawiono na rys. 3 .

Liczba pojazdów zasilanych gazem ziemnym stale wzrasta i osiągnęła wartość około 6,5 miliona w 2007 r. Średni wzrost w porównaniu z rokiem 2000 to 30\%. Największymi rynkami pojazdów zasilanych CNG są obecnie Argentyna, Pakistan i Brazylia. Znaczną część tej floty stanowią pojazdy wykorzystujące proste, niefabryczne instalacje zasilania $\mathrm{CNG}$, które nie spełniają europejskich i amerykańskich standardów emisji. W roku 2007 w Europie było zarejestrowanych około 800000 pojazdów zasilanych CNG (około 400000 we Włoszech, 55000 w Niemczech, 13000 w Szwecji i około 10000 we Francji) i w przybliżeniu 145 000 samochodów w Stanach Zjednoczonych i około 30000 w Japonii [7].

Gaz ziemny wydobywany jest głównie $\mathrm{z}$ szybów gazowych, a także uzyskiwany jako produkt pochodny podczas procesu przetwarzania ropy naftowej. Typowy gaz ziemny zawiera $80 \div 99 \%$ metanu i innych wyższych węglowodorów, a także zanieczyszczenia, takie jak: hel, azot, siarkowodór, dwutlenek węgla

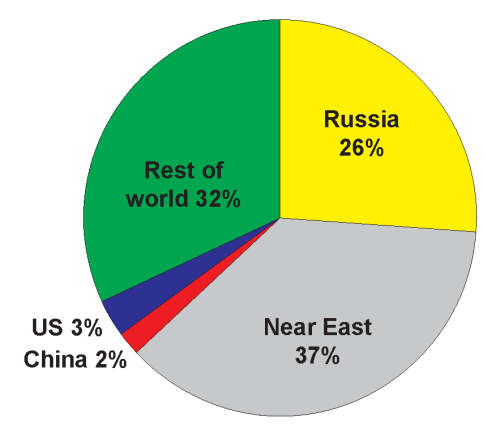

Fig. 3. The locations of the main global natural gas reserves

Rys. 3. Lokalizacja światowych zasobów gazu ziemnego 
and approximately a further 145,000 in the US and around 30,000 in Japan [7].

Natural gas is mainly obtained from gas wells or is driven off as a by-product during crude oil production.

Natural gas typically consists of $80 \div 99$ per cent methane and other gases, higher hydrocarbons as ethane, propane, iso- and n-butane and impurities such as helium, nitrogen, hydrogen sulphide, carbon dioxide and water vapour [18]. Natural gas only requires dehydration and some clean-up steps after extraction. Natural gas can be compressed, so it can be stored in special stainless steel bottles and used as compressed natural gas (CNG). Methane is characterised by soot-free combustion. $\mathrm{CO}_{2}$ emission from vehicles fuelled with methane is typically some 25 per cent lower compared with emissions from the combustion of petrol and diesel. The key properties of natural gas are presented in Table 1 $[8,10]$.

$\mathrm{CNG}$ as a vehicular fuel exhibits significant potential for the reduction of gaseous emissions and particle emissions $[1,2,3,6,16,18,19,20,22,23]$; such effects have been discussed and confirmed in previous studies $[6,7,8]$. CNG also has the potential to achieve reductions of greenhouse gas (GHG) emissions. CNG produced biogenically (biomethane) reduces life-cycle GHG emissions by around 80 per cent, compared to when gasoline is used as a vehicular fuel [9].

\section{CNG technology for light duty vehicles}

Natural gas is commonly used in bi-fuel light-duty vehicles (LDV) and light-commercial-vehicles (LCV) as an alternative to gasoline. At this stage of development, vehicle configurations play a significant role in determining exhaust emissions performance. To meet low exhaust emission limits, dedicated CNG fuelling control systems have to be applied. i parę wodną. Gaz ziemny po wydobyciu wymaga tylko odwodnienia i kilku procesów oczyszczających. Pod koniec tych procesów technologicznych spręża się go w celu uzyskania sprężonego gazu ziemnego (CNG). Metan, główny składnik CNG, charakteryzuje się spalaniem bez wydzielania sadzy. Emisja $\mathrm{CO}_{2}$ przez pojazdy zasilane metanem jest mniejsza o $25 \% \mathrm{w}$ porównaniu do emisji z pojazdów zasilanych benzyną czy olejem napędowym. Główne właściwości gazu ziemnego przedstawiono w tabeli 1 . CNG jako paliwo samochodowe wykazuje potencjał obniżonej emisji spalin gazowych i cząstek stałych [1, 2, 3, 16, 18, 19, 21], co zostało przedyskutowane i udowodnione przez wielu specjalistów $[6,7,8]$. Istnieje także potencjalna możliwość redukcji gazów cieplarnianych. Wprowadzenie CNG produkowanego metodami biogenicznymi (biometan) zmniejsza całkowitą emisję gazów cieplarnianych procesu przygotowania paliwa i spalania w silniku (GHG) do około $80 \%$ w porównaniu do pojazdów napędzanych benzyną [9].

\section{Zasilanie CNG dla lekkich pojazdów samochodowych}

Gaz ziemny zwykle stosowany jest w dwupaliwowych samochodach osobowych i lekkich pojazdach dostawczych jako alternatywne paliwo dla benzyny. Kluczową rolę pod kątem oddziaływania na poziom emisji związków szkodliwych spalin odgrywają zmiany konstrukcyjne wprowadzone w silniku i całym pojeździe. Aby spełnić niskie limity emisji spalin, należy stosować przeznaczone do danych pojazdów systemy zasilania CNG. Z powodu mniejszej entalpii spalania gazu ziemnego w porównaniu do benzyny, należy wprowadzić pewne zmiany w systemie sterowania silnikiem w celu uniknięcia spadku mocy. Z powodu tych strat potrzebna jest optymalizacja parametrów konstrukcyjnych

Table 1. Major properties of Natural Gas

Tabela 1. Główne właściwości gazu ziemnego [3]

\begin{tabular}{|c|c|}
\hline Property (units/conditions)/właściwość (jednostka/warunki) & Value/wartość \\
\hline Carbon to hydrogen ratio/stosunek węla do wodoru & $0.25-0.33$ \\
\hline Relative density/gęstość względna (dla $15^{\circ} \mathrm{C} / 1$ bar) & $0.72-0.81$ \\
\hline Boiling point/temperatura wrzenia $\left({ }^{\circ} \mathrm{C} / 1 \mathrm{bar}\right)$ & -162 \\
\hline Flashpoint/temperatura zapłonu $\left({ }^{\circ} \mathrm{C}\right)$ & $540-650$ \\
\hline Octane number/liczba oktanowa (RON/MON) & $120-130$ \\
\hline Methane number/liczba metanowa & $80-99$ \\
\hline Stoichiometric air/fuel ratio (mass)/wspótczynnik stechiometryczny powietrze/paliwo (masowy) & 17.2 \\
\hline Lower heating value/wartość opałowa & $38-50$ \\
\hline Methane concentration (volume \%)/zawartość metanu (objętości w\%) & $80-99$ \\
\hline Ethane concentration (volume \%)/zawartość etanu (objętości w\%) & $2.7-4.6$ \\
\hline Nitrogen concentration (volume \%)/zawartość azotu (objętości w \%) & $0.1-15$ \\
\hline Carbon dioxide concentration (volume \%)/zawartość ditlenku węgla (objętości w \%) & $1-5$ \\
\hline Sulphur concentration (ppm, mass)/zawartość siarki (ppm, masowa) & $<5$ \\
\hline Wobbe Index $\left(\mathrm{MJ} / \mathrm{m}^{3}\right)^{*} /$ indeks Wobbego $\left(M J / \mathrm{m}^{3}\right) *$ & 41 \\
\hline \multicolumn{2}{|c|}{$\begin{array}{l}\text { * Wobbe Index - the ratio of the specific calorific value of the fuel to its density; this value represents the fuel chemical energy that passes through a specified orifice at a } \\
\text { given pressure drop; the variation of Wobbe index with stoichiometric air/fuel ratio is linear, i.e. } 10 \% \text { increase in Wobbe index leads to } 10 \% \text { increase in equivalence ratio } \\
\text { Indeks Wobbego - stosunek wartości opatowej do gęstości paliwa; wartość przedstawia chemiczna energię paliwa przy przejściu przez specjalna kryzęo określonym } \\
\text { spadku ciśnienia; zależność między Indeksem Wobbego a stosunkiem stechiometrycznym powietrze/paliwo jest liniowa, np. } 10 \% \text { wzrostu Indeksu Wobbego powoduje rów- } \\
\text { noważny 10-procentowy wzrost stosunku powietrze/paliwo }\end{array}$} \\
\hline
\end{tabular}


Because of the lower enthalpy of combustion of natural gas compared with petrol, some changes should be made to the engine control system to avoid power loss. Because of these potential losses, some optimisations are needed which are achieved by charging the $\mathrm{CNG}$ engine or by increasing its compression ratio. High compression ratios are possible due to the high octane rating of methane.

Engine technologies such as variable valve timing (VVT), exhaust gas recirculation (EGR) or highly refined systems for the direct injection of natural gas can help to enhance the emissions performance and improve fuel efficiency of gas engines. Natural gas direct injection systems rely on the late-cycle high pressure injection of gas into the combustion chamber. Natural gas has a higher ignition temperature than conventional liquid fuels and so an ignition aid (pilot spray) is needed.

Natural gas has a high octane number, thus permitting high compression ratios. For this reason, most NG engines operate on spark ignition. Gaseous NG has a low volumetric energy density, but in liquid form this value increases. NG is less dense than air, creating an explosion risk in enclosed spaces. Safety requirements are stricter for $\mathrm{CNG}$ than for LPG, because of the high pressure of CNG storage, however LPG is denser than air and is banned from indoor parking areas, while compressed gas CNG vehicles can normally be parked in indoor and underground garages.

Technology for light-duty CNG vehicles is well established, and CNG vehicles have comparable performance to their petrol-powered counterparts. $\mathrm{CNG}$ is commonly used in spark ignition engines because their powertrains are relatively easy to convert from liquid to gaseous fuels. To improve engine performance while running on CNG fuel, the compression ratio should be optimised for higher RON values (130). The construction of the cylinder head in each case should be customised (geometry, valve and seat materials) for the engine and fuel used, which influences the combustion process, especially the temperature profile. It is advisable to reach spark ignited stoichiometric combustion for all operating conditions so that a three-way catalyst (TWC) improved to convert $\mathrm{CH}_{4}$ can be used. The TWC has to be dedicated to the conversion of $\mathrm{CH}_{4}$, which typically means it has a higher volumetric capacity and higher precious metal loading compared with its gasoline counterpart (typically loading is no less than $300 \mathrm{~g} / \mathrm{ft}^{3}$ at a $\mathrm{Pt}: \mathrm{Pd}: \mathrm{Rh}$ ratio of $1: 28: 2$ and cell density is not less than $600 \mathrm{cpsi}$ ) $[6,17]$. The reason for this is that oxidation of methane is difficult to achieve - vehicles operating on petrol have relatively limited quantities of $\mathrm{CH}_{4}$ in their exhaust gas and are fitted with TWCs optimized for oxidation of heavier hydrocarbons.

Regarding fuel management, the most common $\mathrm{CNG}$ technology is multipoint sequential injection with a dedicated intake manifold. This type of injection is used in bi-fuel cars (petrol and CNG). The principle used in the past by the ECU to calculate the injection timing applied to the $\mathrm{CNG}$ injectors was based on the acquisition of petrol injection timing by the CNG ECU during CNG mode. Therefore, engine management is mainly handled by the petrol ECU - the CNG silnika i jego osprzętu, którą osiąga się przez zastosowanie doładowania, bądź zwiększenie stopnia sprężania. Zastosowanie dużych stopni sprężania jest możliwe dzięki wysokiej liczbie oktanowej metanu. Rozwiązania takie jak zmienne fazy rozrządu (VVT), recyrkulacja spalin (EGR) czy zastosowanie układów wtrysku bezpośredniego gazu ziemnego mogą być pomocne do spełnienia limitów emisji oraz poprawić ekonomiczność silników zasilanych gazem. Systemy bezpośredniego wtrysku gazu ziemnego charakteryzują się opóźnionym wtryśnięciem gazu do komory spalania pod wysokim ciśnieniem. Gaz ziemny ma wyższą temperaturę zapłonu niż konwencjonalne paliwa ciekłe i z tego powodu wymaga stosowania zapłonu wspomaganego (strumień pilotujący). Gaz ziemny ma dużą liczbę oktanową, dzięki czemu możliwe jest stosowanie wysokich stopni sprężania. $Z$ tego względu większość silników zasilanych CNG to silniki ZI. W stanie gazowym gaz ziemny ma małą objętościową gęstość energetyczną, ale w postaci ciekłej wartość ta wzrasta. Gaz ziemny jest lżejszy od powietrza, co powoduje ryzyko wybuchu w pomieszczeniach zamkniętych. Ze względu na wyższe ciśnienie magazynowania gazu w butlach wymogi dotyczące bezpieczeństwa są bardziej restrykcyjne niż dla LPG, jednakże LPG jest cięższy od powietrza, przez co pojazdy zasilane LPG nie mogą korzystać z zamkniętych parkingów, podczas gdy pojazdy z CNG mogą korzystać i z zamkniętych parkingów, i z garaży podziemnych.

Rozwiązania konstrukcyjne dla lekkich pojazdów samochodowych zasilanych CNG są dobrze rozwinięte i pojazdy zasilane CNG mają porównywalne osiągi z ich odpowiednikami zasilanymi benzyną. CNG jest szeroko stosowane w silnikach ZI ze względu na łatwość zaadaptowania tego silnika do wykorzystywania paliw gazowych zamiast płynnych. W celu poprawy osiągów silnika podczas pracy przy zasilaniu CNG stopień sprężania powinien być dostosowany do większej liczby oktanowej paliwa $(\mathrm{RON}=130)$. Konstrukcja głowicy cylindrów zawsze powinna być dobrana (geometria, materiały zaworów i gniazd zaworowych) dla danego silnika i używanego paliwa, bo to wpływa na proces spalania, a zawłaszcza na rozkład temperatur. Dla silników ZI wskazana jest regulacja składu mieszanki gaz-powietrze, która zapewnia spalanie stechiometryczne przy wszystkich warunkach pracy, tak aby poprawić proces utleniania $\mathrm{CH}_{4}$ przez trójfunkcyjny reaktor katalityczny. Reaktor powinien być specjalnie przystosowany do przetwarzania $\mathrm{CH}_{4}$; zwykle ma on większą pojemność objętościową i większą zawartość metali szlachetnych w porównaniu do benzynowego odpowiednika (zazwyczaj metali szlachetnych nie jest mniej niż $300 \mathrm{~g} / \mathrm{ft}^{3}$ w stosunku Pt:Pd:Rh, odpowiednio 1:28:2 i gęstości komórkowej nie mniejszej niż 600 cpsi) [6, 17]. Przyczyną tego jest trudność w utlenianiu metanu - pojazdy napędzane benzyną mają niską zawartość $\mathrm{CH}_{4}$ w spalinach i wyposażone są w reaktory katalityczne zoptymalizowane do utleniania cięższych węglowodorów.

Najczęściej spotykanym sposobem zasilania CNG jest wielopunktowy, sekwencyjny wtrysk gazu wraz z modyfikowanym układem dolotowym. Tego typu układ wtryskowy wykorzystywany jest w dwupaliwowych silnikach samocho- 
control unit translates petrol actuations into an appropriate programme for the CNG injectors by using specific information such as $\mathrm{CNG}$ injector rail pressure, $\mathrm{CNG}$ temperature, engine coolant temperature, engine speed and battery voltage, in addition to inputs from the petrol ECU. In order to maintain harmony with the petrol system, the CNG ECU drives the $\mathrm{CNG}$ injectors in the same sequence as the petrol injectors [6]. This solution was used in OEM systems up to Euro 4 (and is till used for aftermarket systems); from Euro 5 onwards a single, integrated ECU is used to control the engine when operating on either fuel. Currently, the most common bi-fuel systems use petrol start-up engine as their default mode. When the engine is running and the fuel switch is set to CNG mode, the CNG ECU switches fuel from petrol to $\mathrm{CNG}$. The $\mathrm{CNG}$ fuel stored in the tank is vaporised in the pressure regulator so that it can achieve a relative outlet pressure 2 bars above the intake manifold pressure. The solenoid valve installed on the pressure regulator is switched on when the threshold engine coolant temperature is reached. The petrol injectors are switched off when in CNG mode and the integrated ECU assumes control of the $\mathrm{CNG}$ injectors $[6,15]$. Since the vehicle used in this study was a Euro 5 vehicle, it featured a single, integrated ECU to control the injection of both fuels - CNG and gasoline.

CNG vehicles require special high pressure refuelling infrastructure. Without such a network, $\mathrm{CNG}$ cars have no future in the vehicular market - however, it is clear that such a network should be built as production of CNG vehicles increases. Typically, the ratio between $\mathrm{CNG}$ vehicles and CNG refuelling stations varies from 20 to 800 . To achieve profitability, a CNG refuelling station should serve at least 100 light-duty vehicles or smaller numbers of busses consuming an equivalent amount of fuel. This problem is often discussed in conjunction with NG vehicles. Development of CNG refuelling infrastructure is arguably as important as work on emissions from $\mathrm{CNG}$.

Gas-to-Liquid (GTL) fuel is the most cost-effective natural gas-based fuel that can help the European Union reach its transportation fuel aspirations. The EU's 2020 vision for 20 per cent non petroleum-derived road transport fuels can likely only be achieved with natural gas forming part of the range of alternative fuels. In addition to the technical and economic development of GTL, this fuel can help accelerate the development of other XTL options.

\section{Research programme}

\subsection{Methods of emissions testing according to Euro 5 and 6 requirements for $\mathrm{CNG}$ vehicles}

The analysis of exhaust emissions from a bi-fuel vehicle with a spark-ignition engine fuelled with $\mathrm{CNG}$ and, later, with petrol during the NEDC cycle was carried out on a chassis dynamometer in the Emissions testing laboratory (Fig. 4 and 5) of BOSMAL Automotive R\&D Institute in Bielsko-Biala, Poland. The tests presented in this paper were carried out within a research programme investigating the influence of alternative fuels on exhaust emissions from automotive vehicles with spark ignition and compression dowych (benzyna i CNG). Zasada obliczania czasu wtrysku dla wtryskiwaczy gazu przez układ sterujący CNG ECU polega na odwzorowaniu czasów wtrysku benzyny przez układ sterujący ECU podczas pracy w trybie CNG. Dlatego sterowanie zasilaniem silnika w paliwo wykonywane jest głównie przez układ sterowania ECU dla standardowych silników benzynowych - układ sterujący CNG przetwarza sygnały zadawania wtrysku benzyny na odpowiedni program dla wtryskiwaczy CNG, z wykorzystaniem specjalnych informacji, takich jak: ciśnienie gazu w szynie zasilającej wtryskiwacze, temperatura gazu, temperatura płynu chodzącego silnika, prędkość obrotowa silnika i napięcia akumulatora - jako informacje dodatkowe oprócz sygnału pochodzącego ze standardowego układu ECU. Aby utrzymać spójność z układem benzynowym, układ sterujący CNG ECU steruje wtryskiwaczami gazu w tej samej sekwencji jak dla wtryskiwaczy benzyny [6]. Tego typu rozwiązanie było stosowane przez producentów samochodów typu LDV aż do poziomu Euro 4 (i ciągle jest stosowane w rozwiązaniach dotyczących przeróbek rynkowych samochodów benzynowych na zasilanie CNG). Dla samochodów Euro 5 wprowadzono jeden zintegrowany układ startujący ECU, który steruje wtryskiem paliwa i zapłonem silnika dla obu stosowanych paliw. Obecnie najbardziej rozpowszechnione systemy sterowania dla układu dwupaliwowego wykorzystują benzynę w celu uruchomienia silnika, w trybie domyślnym. Po uruchomieniu silnika i przełączeniu w tryb pracy CNG, układ ECU przełącza paliwo z benzyny na CNG. Zmagazynowany gaz $\mathrm{CNG}$ w zbiorniku samochodu jest odparowywany w reduktorze, aby można było uzyskać względne ciśnienie około 2 barów w odniesieniu do ciśnienia w kolektorze dolotowym. Zawór elektromagnetyczny zainstalowany na reduktorze uruchomiony jest w chwili, gdy temperatura czynnika chłodzącego silnik osiągnie zaprogramowany poziom. Wtryskiwacze benzyny zostają wyłączone w chwili przejścia w gazowy tryb pracy i układ ECU rozpoczyna sterowanie wtryskiwaczami gazu $[6,15]$.

Pojazdy zasilane gazem ziemnym CNG wymagają specjalnej, wysokociśnieniowej infrastruktury tankowania pojazdu gazem. Bez tej sieci pojazdy CNG nie mają przyszłości na rynku samochodowym. Jednakże, wiadomo, iż taka sieć powinna być zbudowana z racji rosnącej produkcji i zainteresowania pojazdami zasilanymi CNG. Typowy stosunek między liczbą pojazdów CNG a liczbą stacji tankowania CNG wynosi od 20 do 800. Aby osiągnąć opłacalność przy planowaniu budowy takich stacji, stacje tankowania powinny obsługiwać przynajmniej 100 samochodów osobowych lub dostawczych, lub mniejszą liczbę autobusów, zużywających podobną ilość paliwa. Ten problem często jest przedmiotem dyskusji w odniesieniu do zagadnienia pojazdów zasilanych gazem ziemnym. Rozwój infrastruktury napełniania CNG jest niemal tak ważny, jak praca nad emisją pojazdów zasilanych tym rodzajem paliwa.

Paliwo gazowe w postaci ciekłej (Gas-to-Liquid - GTL) jest najbardziej ekonomicznie efektywnym paliwem opartym na gazie ziemnym, które może pomóc Unii Europejskiej spełnić jej przyszłe plany w dziedzinie transportu. Plano- 
ignition engines. The objective of the research presented here was to determine the influence of CNG fuel usage on exhaust emissions in the context of the new Euro 6 emissions limits, which will be mandated in EU countries from 2014/2015.

Two types of test were performed: continuous pollutant concentration measurements and CVS-bag tests measuring average emission of these pollutants during chassis dynamometer testing. The New European Driving Cycle (NEDC - Fig. 6), introduced in Directive 98/69/EC (8), was selected as a representative test for this study. The test consists of two phases: the Urban Driving Cycle (UDC), followed by the high-speed Extra Urban Drive Cycle (EUDC).

All tests were conducted on a bi-fuel vehicle of European manufacture, powered by an SI engine, fuelled either with a MPI petrol fuel injection system or a MPI natural gas injection system. The vehicle tested was a bi-fuel light duty vehicle, adapted by the manufacturer to run on $\mathrm{CNG}$

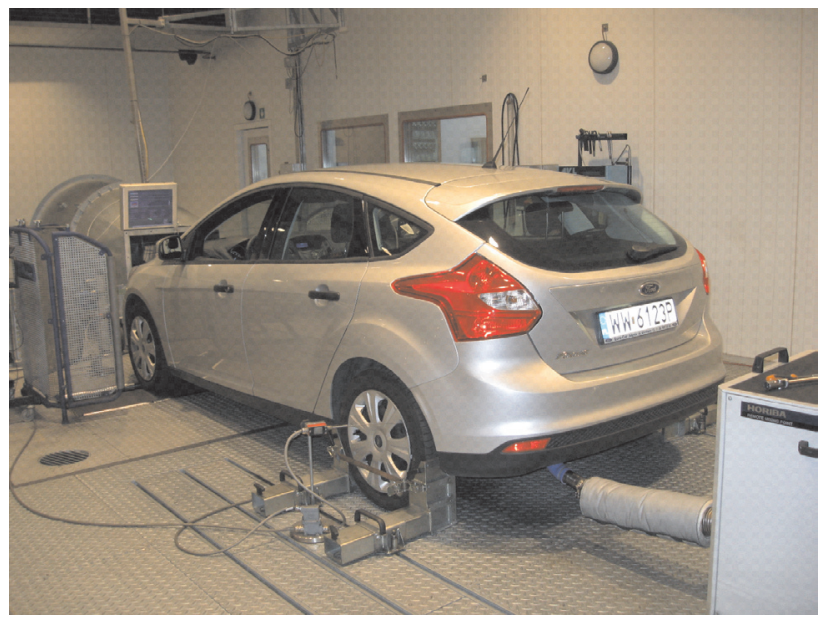

Fig. 4. BOSMAL Emission Testing Laboratory (cell 2) - internal view of the climatic chamber

Rys. 4. Laboratorium Badania Emisji Spalin w Instytucie Badań i Rozwoju Motoryzacji BOSMAL (nr 2) - komora klimatyczna $z$ hamownia podwoziowa

fuel in addition to petrol. The vehicle was equipped with multipoint sequential injection, with a dedicated intake manifold for CNG and an integrated ECU unit with different injection and ignition timing strategies for both petrol and CNG. The engine always starts on petrol and is automatically switched over to $\mathrm{CNG}$ operation after a few seconds (when the vehicle is in CNG mode). The aftertreatment system of the car tested consisted of a three way catalytic converter (TWC) specially adapted for bifuel cars (fueled with petrol and $\mathrm{CNG}$ ). The usage of $\mathrm{CNG}$ fuel also caused some changes in the engine construction of the car tested. The construction of the cylinder head was modified for $\mathrm{CNG}$ operation by changes made to valve and seat materials. The changes to the engine and fuelling system, together with the installation of a larger TWC cause a slight increase in vehicle mass compared to the standard (petrol only) model. wany 20-procentowy udział paliw nieropopochodnych w strukturze rynku paliwowego do 2020 r. jest możliwy do osiągnięcia z zastosowaniem gazu ziemnego, wypełniając część planowanego udziału paliw alternatywnych na rynku paliw silnikowych. Wraz z rozwojem technicznym i ekonomicznym produkcji GTL, to paliwo może pomóc $\mathrm{w}$ przyspieszeniu rozwoju silników zasilanych GTL.

\section{Programy badań}

\subsection{Metody badania emisji spalin z pojazdów zasila- nych CNG zgodnie z wymogami norm Euro 5 i 6}

Analiza emisji spalin z pojazdu dwupaliwowego z silnikiem ZI zasilanego CNG i zasilanego benzyną podczas cyklu jezdnego NEDC przeprowadzona była na hamowni podwoziowej w laboratorium badania emisji spalin (rys. 4 i 5) Instytutu Badań i Rozwoju Motoryzacji BOSMAL w Bielsku-Białej. Badania prowadzono w ramach programu badawczego oceniającego wpływ zastosowania alternatywnych paliw silnikowych na możliwość redukcji emisji związków szkodliwych spalin z pojazdów samochodowych z silnikami ZI i ZS. Celem tych badań było określenie wpływu użycia CNG jako paliwa na poziom emisji spalin w aspekcie nowych limitów emisji związków szkodliwych zawartych w normach Euro 6, które będą obowiązywać we wszystkich krajach Unii Europejskiej.

W czasie testów badawczych prowadzono ciągły pomiar koncentracji poszczególnych związków w spalinach oraz wykonywano analizę składu spalin w workach pomiarowych przy wykorzystaniu metody pomiaru ilości spalin i próbkowania za pomocą układu CVS, mierząc średnią emisję tych związków podczas testu jezdnego samochodu na hamowni podwoziowej. Pomiary wykonano w cyklu jezdnym NEDC (rys. 6), opisanym w Dyrektywie 98/69/EC. Składa się on z dwóch faz: cyklu miejskiego (UDC), a następnie z fazy jazdy z wyższymi prędkościami (EUDC).

Badania prowadzono na samochodzie przystosowanym do zasilania dwupaliwowego (benzyna-CNG), napędzanym silnikiem ZI, zasilanym zarówno z benzynowego wielopunktowego układu wtryskowego, jak i z wielopunktowego, sekwencyjnego układu wtrysku CNG. Badany pojazd był przystosowany fabrycznie do zasilania CNG. Pojazd

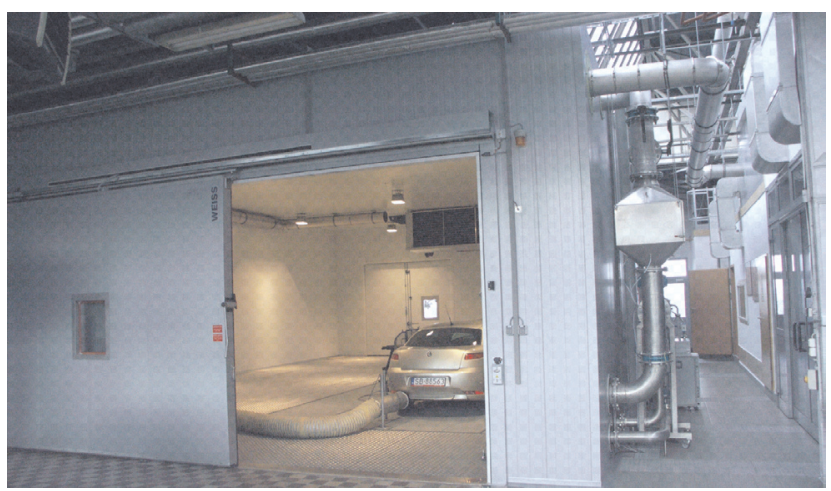

Fig. 5. BOSMAL Emission Testing Laboratory (cell 2) - external view of the climatic chamber

Rys. 5. Laboratorium Emisji Spalin w Instytucie Badań i Rozwoju Motoryzacji BOSMAL (nr 2) - zewnętrzna komora klimatyczna 


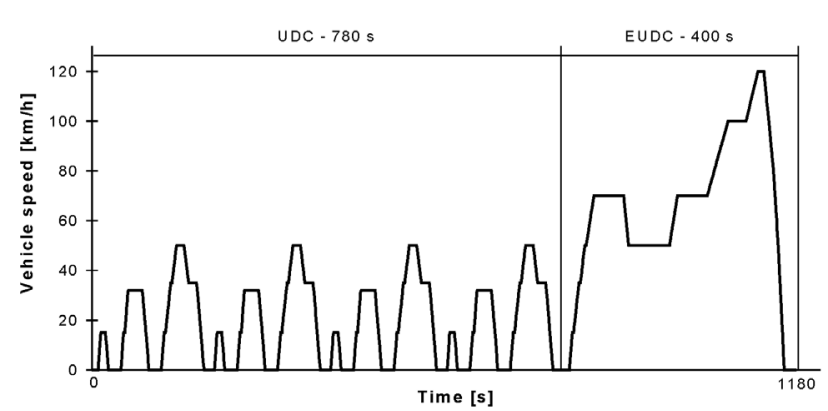

Fig. 6. The New European Driving Cycle (NEDC)

Rys. 6. Nowy europejski cykl jezdny (NEDC)

\subsection{Analysis of CNG emissions in comparison to petrol emissions}

A series of tests were performed on a chassis dynamometer facility on the test vehicle, fuelled with petrol and with $\mathrm{CNG}$ (in turn). Tests were undertaken in order to determine the influence of $\mathrm{CNG}$ fuel on emissions in comparison to Euro5 and 6 limits and in comparison to standard petrol. Results obtained using both fuels are presented side-by-side for ease of comparison. Figs 7, 9, 11, 13 and 15 present the average emissions (in $\mathrm{g} / \mathrm{km}$ ) of THC, NMHC, CO, $\mathrm{NO}_{\mathrm{x}}$ and $\mathrm{CO}_{2}$ for both phases, e.g. the UDC and EUDC, as well as for the complete NEDC (UDC+EUDC) from the test vehicle fuelled both with CNG and with petrol (in turn).

\section{THC, NMHC and CO emissions}

Carbon monoxide $(\mathrm{CO})$ and unburned hydrocarbons (THC) are exhaust gas components which can be effectively removed by a Three Way Catalyst (TWC). The TWC's effectiveness after reaching its light off temperature is high and it is quite satisfactory for the moment. However, there is a problem due to $\mathrm{CO}$ and $\mathrm{THC}$ emissions during cold-start and warm-up conditions (during the first phase of the NEDC i.e. the UDC phase). This means that THC and NMHC emissions during the NEDC (UDC+EUDC) cycle are effectively determined by emission during the UDC phase (Fig. 7 and 9), as the contribution of the second phase (EUDC) is negligible; during the EUDC phase the THC and NMHC emissions were at very low levels for both test fuels, confirming the high effectiveness of the TWC at removing hydrocarbons once it had achieved its light off temperature.

During the UDC phase, and the for entire NEDC, emissions of total hydrocarbons were $17 \%$ higher when running on CNG than when running on petrol (Fig. 7 and 8). However, for NMHC, this situation was reversed (Fig. 9), and NMHC emission was noticeably lower when running on $\mathrm{CNG}$, the difference being approximately $42 \%$. $\mathrm{CH}_{4}$ concentration in tailpipe (TP) gases was much higher when running on $\mathrm{CNG}$ (Fig. 10).

Regarding $\mathrm{CO}$ emissions, the most important part of the NEDC cycle is also engine start-up, with necessary fuel enrichment for proper engine starting and the period during which the TWC has not yet reached light off temperature; emissions during the EUDC phase are much lower (Figs 11 and 12). For CO (Fig. 11), emission was slightly lower during the UDC, but substantially higher during the EUDC, wyposażony był w wielopunktowy, sekwencyjny system wtryskowy ze zmodyfikowanym kolektorem dolotowym dla układu zasilania CNG i zintegrowany układ sterowania ECU. Silnik zawsze był uruchamiany z wykorzystaniem benzyny i po paru sekundach automatycznie przełączany na pracę przy zasilaniu CNG (jeśli pojazd był w trybie pracy na CNG). Układ wylotowy w testowym pojeździe składał się z trójfunkcyjnego reaktora katalitycznego (TWC) przystosowanego dla pojazdów dwupaliwowych (zasilanych benzyną i CNG). Wykorzystanie gazu CNG jako paliwa wymusiło także kilka zmian konstrukcyjnych w silniku testowanego pojazdu. Konstrukcja głowicy cylindrów została zmodyfikowana do pracy z wykorzystaniem $\mathrm{CNG}$, w stosunku do podobnej wersji benzynowej, przez zmianę materiałów wykorzystanych na zawory i gniazda zaworowe. Zmiany w silniku i układzie paliwowym, razem z instalacją układu butli na gaz ziemny i większego reaktora katalitycznego, powodują niewielki wzrost masy pojazdu w porównaniu do masy pojazdu standardowego napędzanego samą benzyną.

\subsection{Analiza emisji spalin $z$ pojazdu zasilanego CNG}

Seria testów badawczych emisji NEDC z wykorzystaniem opisanego wyżej pojazdu, zasilanego kolejno benzyną i gazem $\mathrm{CNG}$, została przeprowadzona na hamowni podwoziowej laboratorium badania emisji spalin. Testy zrealizowano w celu określenia wpływu zasilania pojazdu CNG na emisję spalin w kontekście limitów Euro 5 i Euro 6, a także dla porównania ze standardową benzyną. Na rysunkach 7, 9, 11 i 13 przedstawiono emisję ( $\mathrm{w}$ g/km) THC, NMHC, CO, $\mathrm{NO}_{\mathrm{x}}$ i CO , dla obu faz, np. UDC i EUDC i dla kompletnego cyklu NEDC (UDC+EUDC) dla pojazdu zasilanego zarówno gazem CNG, jak i benzyną. Dodatkowo na rys. 8, 10, 12 i 14 przedstawiono koncentrację powyższych związków, mierzoną w sposób ciągły (na bazie modalnej analizy) podczas pełnego cyklu NEDC (UDC+EUDC).

\section{Analiza poziomu emisji THC, NMHC i CO}

Tlenek węgla (CO) i niespalone węglowodory (THC) są związkami gazów spalinowych, które mogą być efektywnie usunięte (utlenione) przez trójfunkcyjny reaktor katalityczny (TWC). Efektywność reaktorów TWC po osiągnięciu ich temperatury pracy jest wysoka i wynosi około $98 \div 99 \%$. Jednakże istnieje problem powodowany emisją CO i THC podczas rozruchu zimnego silnika i w czasie jego nagrzewania się (podczas pierwszej fazy NEDC, np. faza UDC) Oznacza to, iż emisja THC i NMHC podczas cyklu NEDC (UDC+EUDC) zależy od poziomu emisji podczas fazy UDC (rys. 7 i 9). Dla obu testowanych paliw faza EUDC charakteryzowała się emisją THC i NMHC $(0,004-0,010 \mathrm{~g} / \mathrm{km})$ na bardzo niskim poziomie, potwierdzając wysoką efektywność usuwania przez reaktor katalityczny węglowodorów (kiedy osiągnie właściwą temperaturę pracy).

Podczas fazy UDC i całego cyklu NEDC emisja THC była o $17 \%$ większa dla silnika zasilanego CNG niż dla silnika napędzanego benzyną. Jednakże dla NMHC było zupełnie odwrotnie (rys. 9) i emisja NMHC była zauważalnie niższa podczas pracy na CNG (różnica sięgała $42 \%$ ). Jednocześnie zaobserwowano znacznie większą koncentrację $\mathrm{CH}_{4}$ w gazach wylotowych przy zasilaniu CNG (rys. 10). 
resulting in increased overall emission of $\mathrm{CO}$ when running on CNG (a difference of $18 \%$ over the entire NEDC).

In general, gaseous fuels such as NG permit better airfuel mixing, and therefore have the potential to reduce THC emissions [2]. The increase observed in THC emissions when running on $\mathrm{CNG}$ may have been due to the greater proportion of $\mathrm{CH}_{4}$ in the exhaust $\left(\mathrm{CH}_{4}\right.$ being a difficult molecule to oxidize catalytically in the TWC, as mentioned previously). While emission of THC and CO have the same cause - incomplete combustion - opposing trends were ob-

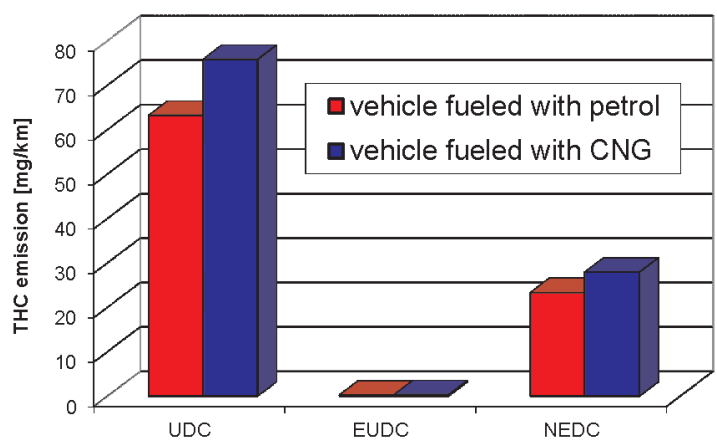

Fig. 7. THC emissions from the UDC and EUDC phases and from the total NEDC cycle for the vehicle fuelled with petrol and CNG in turn

Rys. 7. Emisja THC w trakcie faz UDC i EUDC, a także catego cyklu jezdnego NEDC dla pojazdów zasilanych alternatywnie CNG i benzyna

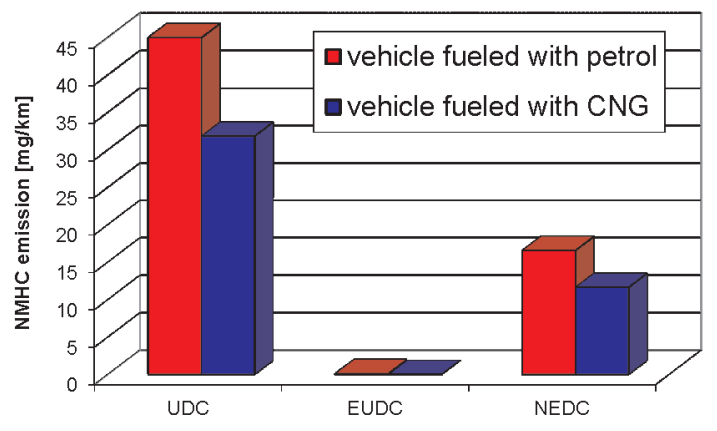

Fig. 9. NMHC emissions from the UDC and EUDC phases and from the total NEDC cycle for the vehicle fuelled with petrol and CNG in turn Rys. 9. Emisja NMHC w trakcie faz UDC i EUDC, a także całego cyklu jezdnego NEDC dla pojazdów zasilanych alternatywnie CNG $i$ benzyna

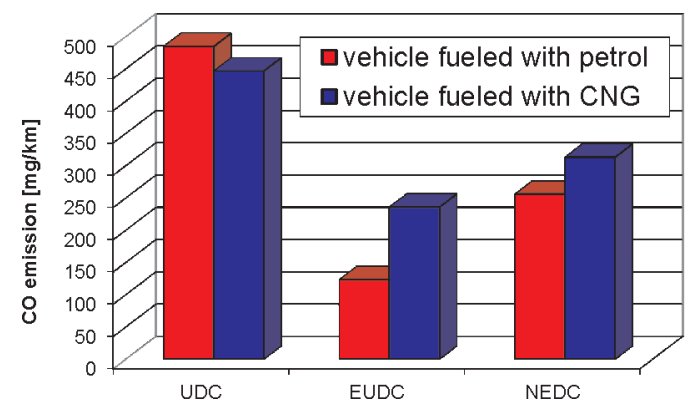

Fig. 11. CO emissions from the UDC and EUDC phases and from the total NEDC cycle for the vehicle fuelled with petrol and CNG in turn

Rys. 11. Emisja CO w trakcie faz UDC i EUDC, a także całego cyklu jezdnego NEDC dla pojazdów zasilanych alternatywnie CNG i benzyna
Gdy wzięto pod uwagę emisję CO, okazało się, że najważniejszą częścią cyklu NEDC był moment uruchomienia silnika, z koniecznym wzbogaceniem mieszanki paliwo-powietrze, dla zapewnienia poprawnego rozruchu silnika, i czas jego pracy bezpośrednio po nim następujący, podczas którego reaktor katalityczny nie osiągnął odpowiedniej temperatury pracy. W następnych fazach pracy silnika $\mathrm{w}$ cyklu EUDC emisja jest już znacznie mniejsza (rys. 11 i 12), ale ze względu na większą emisję w pierwszej fazie,

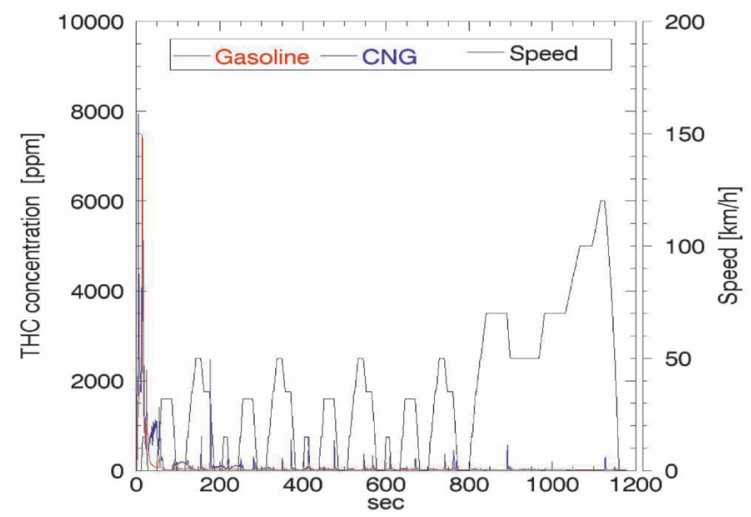

Fig. 8. Tailpipe THC concentration during the NEDC cycle for the vehicle fuelled with petrol and CNG in turn

Rys. 8. Stężenie THC w spalinach podczas cyklu jezdnego NEDC dla pojazdów zasilanych alternatywnie CNG i benzyna

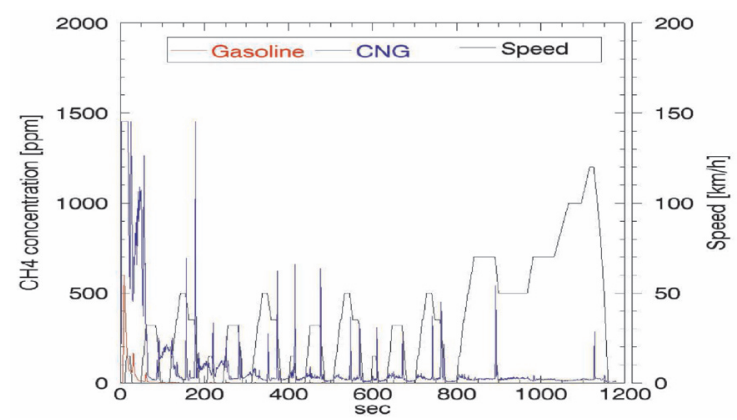

Fig. 10. Tailpipe $\mathrm{CH}_{4}$ concentration during the NEDC cycle for the vehicle fuelled with petrol and $\mathrm{CNG}$ in turn

Rys. 10. Stężenie $\mathrm{CH}_{4}$ w spalinach podczas cyklu jezdnego NEDC dla pojazdów zasilanych alternatywnie CNG i benzyna

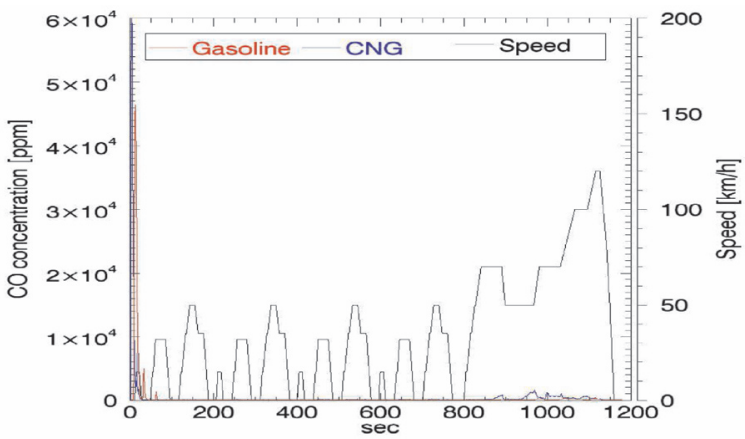

Fig. 12. Tailpipe CO concentration the NEDC cycle for the vehicle fuelled with petrol and CNG in turn

Rys. 12. Stężenie CO w spalinach podczas cyklu jezdnego NEDC dla pojazdów zasilanych alternatywnie CNG i benzyna 
served when operation on $\mathrm{CNG}$ and operation on petrol were compared. The relatively low carbon fraction present in the fuel reduces the air required to achieve the complete oxidation of the carbon present in the fuel, thereby reducing emission of $\mathrm{CO}$, as more carbon atoms are fully oxidized to $\mathrm{CO}_{2}$. Additionally, there is less carbon in the fuel to form CO. Improved mixture formation (as a result of usage of a gaseous fuel), also makes the mixture less heterogeneous and reduces $\mathrm{CO}$ formation somewhat. In light of these considerations, it is somewhat surprising that $\mathrm{CO}$ emission was higher during the second phase when running on CNG. It is possible that the enrichment required for high load sections of the EUDC was more pronounced when running on $\mathrm{CNG}$, thereby causing greater emissions of CO. (However, it should be noted that $\mathrm{CO}$ emissions were low for both fuels, being well below the Euro 6 limit.)

\section{NO emissions}

$\mathrm{NO}$ formation is influenced by flame temperature effects and ignition delay effects driven by fuel chemistry (e.g. the proportion of methane and the content of other, heavier hydrocarbons in the fuel) and fluid dynamics. Additionally, an effect caused by the interaction of the higher specific energy content of methane with the engine control system which was calibrated using gasoline as a base fuel has an influence on $\mathrm{NO}_{\mathrm{x}}$ emissions. At higher loads (e.g. the EUDC phase), characterized by diffusion flame combustion, the flame temperature effect is dominant. Emissions of $\mathrm{NO}_{\mathrm{x}}$ from the vehicle when fuelled with petrol were almost twice as high as when the vehicle was running on $\mathrm{CNG}$ (Fig. 13). $\mathrm{NO}_{\mathrm{x}}$ emissions increased rapidly during each period of acceleration in the UDC phase for the petrol fuel. A similar trend (but with smaller peaks) was observed when running on CNG.

The combustion of NG occurs at a higher temperature than for conventional fuels - in this case petrol, due to the high isentropic value of methane. These higher temperatures can lead to increased formation of oxides of nitrogen. (However, increased temperatures also tend to reduce somewhat the time required for the TWC to reach its light off temperature).

Nitrogen oxides can be formed through three different mechanisms during the combustion process. At low temperatures, nitrogen present in the fuel can react with oxygen in the intake air to produce oxides of nitrogen. Other processes generally require high temperatures and thus localized areas of high temperature (hotspots) have a significant impact on $\mathrm{NO}_{\mathrm{x}}$ formation [4]. The dramatically lower $\mathrm{NO}_{\mathrm{x}}$ emission results presented here may be at least partially due to greater thermal homogeneity within the cylinder (higher average temperature, but fewer hotspots) when running on $\mathrm{CNG}$ than on petrol. The substantial reduction in $\mathrm{NO}_{x}$ emission observed for both phases when running on $\mathrm{CNG}$ is noteworthy and could well have resulted from the improved mixing permitted by use of a gaseous fuel (CNG).

\section{CO, emissions}

$\mathrm{CO}_{2}$ emission results are shown for $\mathrm{CNG}$ and petrol in Figs 15 and 16. It can be noted that these emissions are about $32 \%$ lower for CNG fuel than for petrol in both phases, as ogólny wynik emisji dla silnika zasilanego CNG był o $18 \%$ większy niż dla silnika benzynowego.

Paliwa gazowe, takie jak gaz ziemny, lepiej mieszają się z powietrzem, co stanowi możliwość obniżenia emisji THC [2]. Zwiększona emisja THC zaobserwowana podczas spalania CNG może być spowodowana zwiększoną zawartością $\mathrm{CH}_{4}$ w spalinach (jak wyjaśniono wcześniej, $\mathrm{CH}_{4}$ źle utlenia się w reaktorze katalitycznym). Pomimo tego, że emisja THC i CO ma ten sam powód - niecałkowite spalanie - zaobserwowane skutki były zupełnie inne dla silników benzynowych i zasilanych CNG. Względnie mała frakcja węglowa występująca w paliwie ogranicza ilość powietrza potrzebnego do całkowitego utlenienia zawartego w paliwie węgla, co skutkuje mniejszą emisją $\mathrm{CO}$, gdyż więcej atomów węgla jest w pełni utlenionych do $\mathrm{CO}_{2}$. Dodatkowo w paliwie jest mniej węgla mogącego się utlenić do CO. Poprawione mieszanie (wynikające $\mathrm{z}$ zastosowania paliwa gazowego) sprawia, iż mieszanina jest mniej heterogeniczna, a to prowadzi do ograniczenia emisji CO. W świetle tych faktów zaskakująca wydaje się większa emisja CO zaobserwowana w trakcie fazy drugiej dla silnika napędzanego CNG. Możliwe, iż wzbogacanie mieszanki wymagane do wykonania nagłych przyspieszeń samochodu i dużego obciążenia podczas fazy testu EUDC spowodowało wzrost emisji ze spalania CNG. Należy jednak dodać, że całkowita emisja CO była nie tylko bardzo mała, ale także o wiele mniejsza niż limity dopuszczane przez Euro 6.

\section{Analiza emisji NO}

Formowanie się tlenków azotu $\mathrm{NO}_{\mathrm{x}}$ zależy od temperatury płomienia i efektu opóźnienia zapłonu, warunkowanego składem chemicznym paliwa (np. zawartość czystego metanu i cięższych węglowodorów) i dynamiką płynów. Efekt ten może być spowodowany wyższą wartością energii zawartej w metanie, która nie jest kompensowana przez regulację systemu zasilania gazem, a która jest adaptowana $\mathrm{z}$ układu sterowania wtryskiem benzyny. Opisany efekt może mieć również wpływ na poziom emisji $\mathrm{NO}_{\mathrm{x}}$. Przy dużych obciążeniach (np. faza EUDC) proces spalania charakteryzowany jest przez płomień dyfuzyjny, temperatura płomienia jest dominująca.

Emisja $\mathrm{NO}_{\mathrm{x}} \mathrm{z}$ badanego pojazdu zasilanego CNG była około dwukrotnie mniejsza niż pojazdu zasilanego benzyną (rys. 13). Różnice między koncentracją $\mathrm{NO}_{x}$ w spalinach wyraźnie widoczne są na rys. 14. Emisja $\mathrm{NO}_{\mathrm{x}}$ gwałtownie wzrasta podczas każdego okresu przyspieszania w fazie UDC dla pojazdu zasilanego benzyną.

Spalanie gazu ziemnego przebiega przy wyższej temperaturze niż dla paliw konwencjonalnych - w tym przypadku benzyny, z racji wyższej wartości izentropowej metanu. Tak wysokie temperatury prowadzą do wzrostu ilości formowanych tlenków azotu. Jednakże wzrost temperatury powoduje przyspieszenie osiągnięcia przez trójfunkcyjny reaktor katalityczny jego temperatury pracy.

$\mathrm{NO}_{\mathrm{x}}$ mogą być formowane w wyniku trzech różnych mechanizmów w czasie procesu spalania. Przy niskich temperaturach azot będący $\mathrm{w}$ paliwie może reagować $\mathrm{z}$ tlenem zawartym w powietrzu dolotowym, tworząc tlenki 


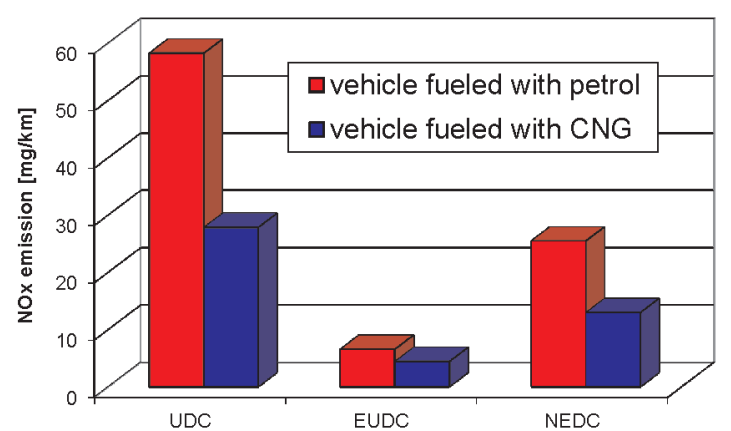

Fig. 13. $\mathrm{NO}_{\mathrm{x}}$ emissions from the UDC and EUDC phases and from the entire NEDC cycle for the vehicle fuelled with petrol and $\mathrm{CNG}$ in turn Rys. 13. Emisja $N_{r}$ w trakcie faz UDC i EUDC, a także całego cyklu jezdnego NEDC dla pojazdów zasilanych alternatywnie CNG i benzyna

well as in the complete NEDC cycle, mainly no doubt due to the lower carbon fraction found in CNG than in petrol.

The main component of natural gas is methane, which, consisting of one carbon atom and four hydrogen atoms, has a $\mathrm{H} / \mathrm{C}$ ratio of $4: 1$. Other combustible trace components are somewhat less hydrogen-rich, but the four next most abundant species typically present in commercial vehicle fuel natural gas (1) all have $\mathrm{H}: \mathrm{C}$ ratios $\geq 2.4: 1$. Assuming a minimum $\mathrm{CH}_{4}$ content of 90 per cent, $\mathrm{NG}$ can be assumed to have a minimum $\mathrm{H} / \mathrm{C}$ ratio of around $3.85: 1$. In contrast, petrol has a much lower ratio of 1.86:1. Emission of $\mathrm{CO}_{2}$ is a function of fuel consumption, as well as fuel $\mathrm{H}: \mathrm{C}$ ratio, and using a fuel with a higher $\mathrm{H}$ : $\mathrm{C}$ ratio does not always guarantee reduced $\mathrm{CO}_{2}$ emissions, but for the for the vehicle used in this study the resulting effect was significantly reduced $\mathrm{CO}_{2}$ emissions. While the Euro 6 regulations do not cover $\mathrm{CO}_{2}$, this finding is of note, as vehicles meeting the Euro 6 standard will also have to comply with other pieces of EU legislation governing fleet average $\mathrm{CO}_{2}$ emissions.

\section{Conclusions and summary}

The main aim of this paper was to determine the influence of CNG fuel on emissions in the context of the new Euro 6 emissions requirements. An analysis was performed on a Euro 5 bi-fuel light duty vehicle in comparison to emissions when the vehicle was fuelled with gasoline.

On the basis of the analyses of results obtained during the NEDC emissions test, it has been found that the vehicle tested with a CNG multipoint gas injection and an integrated (petrol/CNG) ECU already meets the Euro 6 emissions limits, without any further modifications, in particular:

1. CO, THC and NMHC emissions meet Euro 5/6 limits for the LDV category. Observed THC emissions were even relatively close to the NMHC limit stipulated by these regulations, so emissions limits in this area were comfortably met. NMHC emissions were almost $50 \%$ under the Euro 6 limit when running on CNG.

2. THC emissions during the NEDC cycle increased when the vehicle was fuelled with $\mathrm{CNG}$, in comparison to petrol, but this increase was far too small to cause problems with the Euro 6 emissions limit.

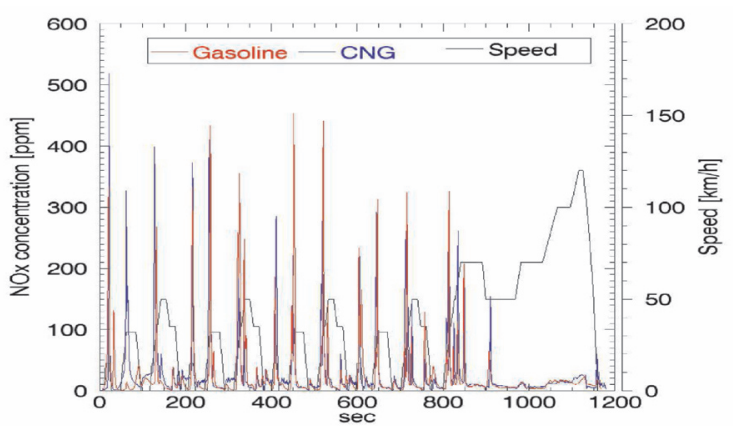

Fig. 14. Tailpipe $\mathrm{NO}_{\mathrm{x}}$ concentration during the NEDC cycle for the vehicle fuelled with petrol and $\mathrm{CNG}$ in turn

Rys. 14. Stężenie $N O_{x}$ w spalinach podczas cyklu jezdnego NEDC dla pojazdów zasilanych alternatywnie $C N G$ i benzyna

azotu. Inny proces generalnie wymaga wysokich temperatur, a zatem lokalizacja obszarów wysokich temperatur (miejsc gorących) ma znaczący wpływ na formowanie się $\mathrm{NO}_{x}$ [4]. Ewidentnie mniejsza emisja $\mathrm{NO}_{x}$, prezentowana wyżej, może być częściowo spowodowana lepszą termalną jednorodnością w cylindrze (wyższa średnia temperatura, ale mniej miejsc ,gorących”) podczas zasilania pojazdu gazem CNG. Zaobserwowaną redukcję w emisji $\mathrm{NO}_{\mathrm{x}}$ podczas obu faz cyklu jezdnego dla silnika zasilanego CNG można wytłumaczyć lepszym mieszaniem się powietrza $\mathrm{z}$ paliwem gazowym.

\section{Emisja $\mathrm{CO}_{2}$}

Na rysunkach 15 i 16 przedstawiono wyniki emisji $\mathrm{CO}_{2}$ zarówno dla $\mathrm{CNG}$, jak i benzyny. Można zauważyć, iż ta emisja jest o około $24 \%$ mniejsza dla paliwa CNG niż dla benzyny w obu fazach testu jezdnego, jak również w kompletnym cyklu NEDC, z powodu mniejszej zawartości węgla (C) w gazie ziemnym w porównaniu do benzyny.

Głównym składnikiem gazu ziemnego jest metan, który zawiera jeden atom węgla i 4 atomy wodoru, posiada stosunek H/C o wartości 4:1. Inne palne, śladowe składniki są raczej uboższe w wodór, ale kolejne cztery o największym udziale w składzie gazu ziemnego, jako paliwa dla pojazdów samochodowych, posiadają stosunek H/C $\geq 2.4: 1$. Gdy założy się minimalną zawartość $\mathrm{CH}_{4}$ na poziomie $90 \%$, gaz ziemny może mieć przewidywany minimalny stosunek $\mathrm{H} / \mathrm{C}$ na poziomie 3.85:1. Dla porównania: benzyna czy olej napędowy zasadniczo mają niższe stosunki H/C - odpowiednio 1.89:1 i 1.86:1. Emisja $\mathrm{CO}_{2}$ jest funkcją zużycia paliwa, a także stosunku H:C. Wykorzystanie paliwa o większym współczynniku $\mathrm{H}: \mathrm{C}$ nie zawsze gwarantuje redukcję $\mathrm{CO}_{2}$, jednak dla pojazdu wykorzystanego w tym teście emisja $\mathrm{CO}_{2}$ była mniejsza. Pomimo tego, że wymagania Euro 6 nie regulują kwestii poziomu emisji $\mathrm{CO}_{2}$, to warto zauważyć, że pojazdy spełniające tę normę, będą musiały spełniać inne europejskie wymogi dotyczące średniej emisji flotowej $\mathrm{CO}_{2}$.

\section{Wnioski i podsumowanie}

Głównym celem niniejszej pracy było określenie wpływu zastosowania paliwa gazowego CNG na emisję szkodliwych składników spalin silnikowych w aspekcie nowych przepisów emisyjnych Euro 6. Analizę przeprowadzono z 


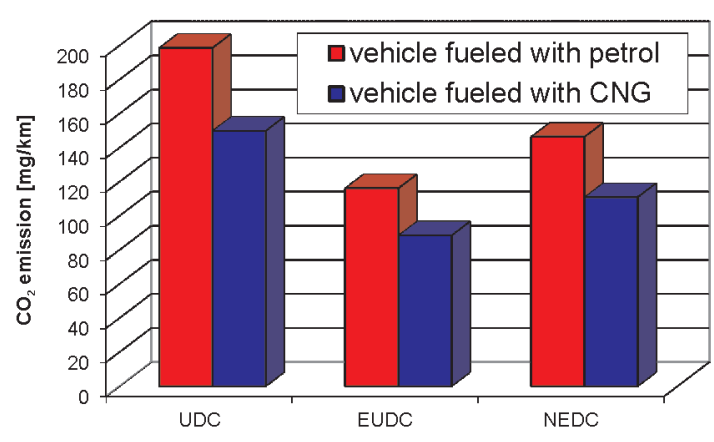

Fig. 15. $\mathrm{CO}_{2}$ emissions from the UDC and EUDC phases and from the entire NEDC cycle for the vehicle fuelled with petrol and CNG in turn

Rys. 15. Emisja w trakcie faz UDC i EUDC, a także całego cyklu jezdnego NEDC dla pojazdów zasilanych alternatywnie CNG $i$ benzyna

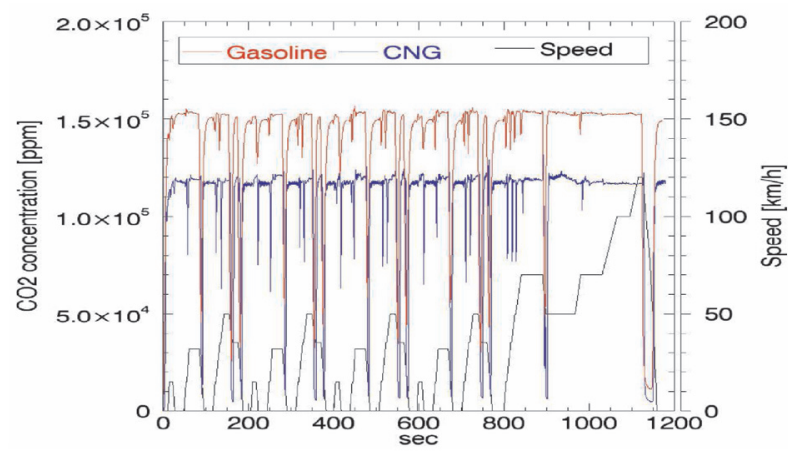

Fig. 16. Tailpipe $\mathrm{CO}_{2}$ concentration during the NEDC cycle for the vehicle fuelled with petrol and CNG in turn

Rys. 16. Stężenie $\mathrm{CO}_{2}$ w spalinach podczas cyklu jezdnego NEDC dla pojazdów zasilanych alternatywnie $C N G$ i benzyna

3. CO emission during the NEDC cycle decreased by $18 \%$ when the vehicle was fuelled with $\mathrm{CNG}$, although $\mathrm{CO}$ emission from both fuel types was well below the limit.

4. $\mathrm{NO}_{\mathrm{x}}$ emissions from the vehicle when fuelled with $\mathrm{CNG}$ met limits for both Euro 5 and Euro 6, and were about 2 times lower in comparison to petrol.

5. $\mathrm{CO}_{2}$ emissions were decreased by $30 \%$ when the vehicle was fuelled with $\mathrm{CNG}$.

6. For the first phase (the UDC), which is critical for determining total emissions during the NEDC, emissions of $\mathrm{NMHC}, \mathrm{CO}$ and $\mathrm{NO}_{\mathrm{x}}$ were all lower when the vehicle was running on $\mathrm{CNG}$ than when it was running on petrol.

Emissions results presented here are more favourable than a comparable study by the authors of this paper [7], which used a Euro 4 vehicle for testing. Assuming these two test vehicles are representative of passenger cars their age, it would appear that a considerable improvement has been made. This is most likely due to improvements in the engine/ECU calibration, making the fuel delivery strategy and overall combustion process more compatible with usage of CNG. Additionally, improvements to the aftertreatment system (TWC) could also have helped to improve emissions performance somewhat.

The technology currently in use for light-duty $\mathrm{CNG}$ vehicles, with new generation fuelling systems, is well advanced and $\mathrm{CNG}$ vehicles have performance comparable wykorzystaniem samochodu osobowego zasilanego CNG, spełniającego wymagania normy Euro 5, odnosząc uzyskane wyniki badań do poziomu emisji pojazdu zasilanego alternatywnie benzyną.

Na podstawie przeprowadzonej analizy wyników uzyskanych podczas cyklu NEDC stwierdzono, iż testowy pojazd z wielopunktowym wtryskiem gazu i dodatkowym układem sterującym ECU spełnia limity emisji zawarte w normach Euro 5 i Euro 6, bez dalszych modyfikacji, w szczególności:

1. Emisja CO, THC i NMHC spełnia limity norm Euro 5 i Euro 6 dla kategorii lekkich pojazdów samochodowych. Zaobserwowana emisja THC była bliska limitom NMHC określonym w tych normach, więc wszystkie wymagania zostały spełnione. Emisja NMHC była o 50\% poniżej wymagań normy Euro $6 \mathrm{w}$ czasie zasilania pojazdu CNG.

2. Emisja THC podczas cyklu NEDC była większa dla pojazdu napędzanego CNG niż dla pojazdu zasilanego benzyną, jednak ten wzrost był niewielki i nie sprawiał problemów ze spełnieniem normy Euro 6.

3. Emisja CO podczas cyklu NEDC wzrastała o $18 \%$, gdy pojazd zasilany był gazem $\mathrm{CNG}$, jednak emisja z obu typów silników była znacznie poniżej limitów Euro 6 .

4. Emisja $\mathrm{NO}_{\mathrm{x}} \mathrm{z}$ pojazdu zasilanego $\mathrm{CNG}$ spełniała limity zarówno normy Euro 5, jak i Euro 6, a w porównaniu do pojazdu zasilanego benzyną była dwukrotnie mniejsza.

5. Emisja $\mathrm{CO}_{2}$ była mniejsza o $32 \%$ przy zasilaniu pojazdu gazem $\mathrm{CNG}$.

6.Podczas fazy UDC, która była kluczowa ze względu na poziom całkowitej emisji w czasie trwania testu NEDC, emisja NMHC, $\mathrm{CO}$ i $\mathrm{NO}_{x}$ była mniejsza dla pojazdu zasilanego $\mathrm{CNG}$.

Zaprezentowane wyniki pomiarów emisji związków szkodliwych spalin pojazdu zasilanego CNG są znacznie korzystniejsze niż osiągnięte w porównywalnych badaniach przeprowadzonych przez autorów niniejszej pracy i przedstawionych w publikacji [8]. Wtedy do badań i analiz użyto samochodu spełniającego wymagania normy Euro 4. Zakładając, że te dwa pojazdy testowe są reprezentatywne dla danego okresu produkcji, można zaobserwować znaczną poprawę osiąganych wyników emisji. Przyczynia się do tego najprawdopodobniej ulepszona regulacja silnika przez układ sterowania ECU, dzięki czemu proces spalania jest lepiej zaprojektowany dla zasilania CNG. Dodatkowo zastosowanie specjalnych rektorów katalitycznych w systemie oczyszczania spalin korzystnie wpłynęło na redukcję emisji.

Obecne w lekkich pojazdach samochodowych napędzanych CNG rozwiązania układu zasilania silnika gazem, wykorzystujące układ paliwowy najnowszej generacji, są bardzo zaawansowane technicznie, a osiągi pojazdów zasilanych CNG są porównywalne z ich odpowiednikami zasilanymi benzyną. Biorąc jednak pod uwagę wyniki emisji CO i THC w odniesieniu do benzyny wydaje się, iż można jeszcze bardziej poprawić emisję tych szkodliwych składników spalin, przez dalszy rozwój zintegrowanych układów sterowania ECU, a przez to dokładniejszą regulację systemu zasilania CNG i dalszy rozwój katalitycznych układów oczyszczania spalin przystosowanych do paliw gazowych. 
to their petrol-fuelled equivalents. However, looking at the THC emissions results in comparison to petrol, it can be seen that emissions performance still could be improved by better CNG fuelling and optimised ignition timing calibration, as well as some further refinement of the TWC.

In this study, $\mathrm{CNG}$ was observed to perform well in terms of emissions. However, this study has focussed only on regulated emissions (as defined in the Euro 6 legislation). Usage of alternative fuels (and particularly gaseous fuels) affects the combustion process in many ways, which includes impacts on exhaust emissions of compounds which are not currently regulated - for example ammonia $\left(\mathrm{NH}_{3}\right)$. Recent research implies that usage of $\mathrm{CNG}$ could have measureable impacts on emissions of ammonia [4]. Research on CNG should also consider the impact on unregulated exhaust pollutant species, as future legislation may set limits for emission of $\mathrm{NH}_{3}$ and other species.

$\mathrm{CNG}$ is commonly used in spark ignition engines because their powertrains are relatively easy to convert from liquid to gaseous fuels. This fuel is very attractive as it is cheaper than gasoline or diesel. It is also very attractive from the environmental protection point of view, as it causes inherently lower air pollution emissions and is associated with lower greenhouse gas emissions. This paper has shown that even certain pre-Euro 6 technologies can meet Euro 6 emissions standards when $\mathrm{CNG}$ is used as a fuel. Additionally, the $\mathrm{CO}_{2}$ emissions from vehicle operation on $\mathrm{CNG}$ are low. For both these reasons, interest in producing and marketing bi-fuel passenger cars for the European market (among others) is sure to remain high, notwithstanding the current inequalities in NG distribution infrastructure and local availability.

\section{Acknowledgment}

The authors would like to thank Joseph Woodburn for proofreading the manuscript and his valuable comments and suggestions.

Paper reviewed/Artykut recenzowany
W przeprowadzonych badaniach zaobserwowano, iż zastosowanie $\mathrm{CNG}$ jako paliwa pozytywnie wpływa na poziom emisji związków szkodliwych spalin. Badania te dotyczyły jednak określenia jedynie emisji limitowanych składników spalin (zgodnie z wymaganiami Euro 6). Wykorzystanie paliw alternatywnych ma duży wpływ na proces spalania, który obejmuje emisję związków nieobjętych jeszcze normami - na przykład amoniaku $\left(\mathrm{NH}_{3}\right)$. $\mathrm{Z}$ najnowszych badań, prowadzonych również przez autorów pracy [4], wynika, że korzystanie z CNG ma zauważalny wpływ na poziom emisji amoniaku. Badania wpływu zasilania CNG jako paliwa silnikowego powinny więc brać pod uwagę emisję związków dotąd nielimitowanych, ponieważ przyszłe ustawodawstwo może ustanowić również limity emisji dla dla $\mathrm{NH}_{3}$.

CNG jest powszechnie używanym paliwem w silnikach o zapłonie iskrowym, ponieważ te jednostki napędowe wymagają niedużych przeróbek do zasilania paliwem gazowym. Atrakcyjność tego paliwa dla użytkowników pojazdów polega głównie na jego niższej cenie rynkowej w porównaniu do benzyny czy oleju napędowego. Jest to również paliwo interesujące z punktu widzenia ekologii transportu, gdyż jego użycie charakteryzuje się małą emisją związków szkodliwych spalin, a także generuje mniejszą ilość gazów cieplarnianych.

Przeprowadzone badania i analizy pokazują, że nawet rozwiązania konstrukcyjne opracowane na kilka lat przed wprowadzeniem przepisów UE Euro 6 mogą spełniać wymagania w zakresie przyszłych norm emisji związków szkodliwych spalin, jeśli jako paliwo silnikowe zostanie zastosowane CNG. Dodatkową zaletą eksploatacji CNG jest znacznie mniejsza emisja $\mathrm{CO}_{2}$. $\mathrm{Z}$ obu tych powodów rośnie stopniowo zainteresowanie pojazdami dwupaliwowymi zasilanymi alternatywnie benzyną i CNG na rynku europejskim i to pomimo obecnych niedoborów infrastruktury umożliwiającej tankowanie CNG oraz wynikającej z tego małej dostępności tego paliwa przy powszechnej eksploatacji samochodu na różnych rynkach europejskich.

\footnotetext{
Abbreviations/Wykaz skrótów

$\mathrm{CH}_{4}$ methane/metan

$\mathrm{CNG}$ compressed natural gas/sprężony gaz ziemny

$\mathrm{CO}$ carbon monoxide/tlenek węgla

$\mathrm{CO}_{2}$ carbon dioxide/dwutlenek węgla

cpsi cells per square inch/ilość komórek na cal kwadratowy

CVS constant volume sampling/próbkowanie o stałej objętości

DI direct (gasoline) injection/bezpośredni wtrysk (benzyny)

DPF Diesel Particulate Filter/filtr czastek statych

EC European Commission/Komisja Europejska

ECE Economic Commission for Europe/Europejska Komisja Gospodarcza (ONZ)

ECU electronic control unit/elektroniczna jednostka sterujaca

EGR exhaust gas recirculation/recyrkulacja gazów wylotowych

EU European Union/Unia Europejska

EUDC Extra Urban Driving Cycle/pozamiejski cykl jezdny

GHG greenhouse gases/gazy cieplarniane

GTL gas to liquid/ciekle paliwo z gazu

HC hydrocarbons/węglowodory
}

LCV Light-Commercial Vehicle/samochód dostawczy

LDV Light-Duty Vehicle/lekki pojazd samochodowy

MPI multi point (fuel) injection/wielopunktowy wtrysk paliwa

NEDC New European Driving Cycle/nowy europejski cykl jezdny

NG natural gas/gaz ziemny

$\mathrm{NH}_{3}$ ammonia/amoniak

NMHC Non-methane hydrocarbons/wegglowodory niemetanowe

$\mathrm{NO}_{x} \quad$ nitrogen oxides/tlenki azotu

PC Passenger Car/samochód osobowy

$\mathrm{Pt}$ platinum/platyna

Pd palladium/pallad

$\mathrm{Rh}$ rhodium $/ \mathrm{rod}$

RON research octane number/badawcza liczba oktanowa

SI spark ignition/zapłon iskrowy

THC total hydrocarbons/węglowodory (calkowita ilość)

TP tailpipe/emisja $z$ uktadu wylotowego

UDC Urban Driving Cycle/miejski cykl jezdny

VVT variable valve timing/zmienne fazy rozrządu

XTL X-to-liquid/ptynne paliwo z produktu X 


\section{Bibliography/Literatura}

[1] Allgeier T., Bischoff C., Foerster J.: Natural Gas as an alternative fuel for motor vehicles, F2004V040, 2004 FISITA World Congress.

[2] Bhandari K., Bansal A., Shukla A., Khare M.: Performance and emissions of natural gas fuelled internal combustion engine: A review. Journal of Scientific \& Industrial Research, Vol. 64, May 2005, p. 333-338.

[3] Bielaczyc P., Świątek A.: Clean and energy efficient vehicle powertrains and fuels - from today to 2030 vision. "Environment Friendly Surface Transport” PolSCA Meeting, Brussels, 10.04.2008.

[4] Bielaczyc P., Szczotka A., Swiatek A., Woodburn J.: A Comparison of Ammonia Emission Factors from Light-Duty Vehicles Operating on Gasoline, Liquefied Petroleum Gas (LPG) and Compressed Natural Gas (CNG), SAE Int. Journal Fuels Lubr. 5(2):2012, doi:10.4271/2012-01-1095. 2012 SAE International World Congress, Detroit, USA.

[5] Bielaczyc P.: IC Engine Test Method Development Regarding Emissions, Alternative Fuels, Lubricants and Future Trends. $2^{\text {nd }}$ International Exhaust Emissions Symposium. Symposium Proceedings on CDRom, 26/27 May 2011, ISBN 978-83-931383-1-9.

[6] Bielaczyc P., Szczotka A.: An analysis of exhaust emissions from vehicle fuelled with CNG. Materiały VI międzynarodowej konferencji naukowej "Silniki gazowe 2003”, Częstochowa-Szczyrk, 2-6.06.2003, Zeszyty Naukowe Politechniki Częstochowskiej, 155, Mechanika 25.

[7] Bielaczyc P., Szczotka A., Wojnarowicz M.: Analysis of the exhaust emissions and performance of a modern vehicle fuelled with petrol and CNG alternatively. FISITA Paper F2010-A133, FISITA World Automotive Congress, Budapest 2010.

[8] Bielaczyc P.: An analysis of CNG fuelling influence on the reduction of exhaust emissions from motor vehicles. Proceedings of the 3rd IMechE Conference on Total Vehicle Technology, University of Sussex, Brighton, UK, 26-27 April 2004.

[9] Borderlanne O., Montero M., Bravin F. et al.: Biomethane CNG Hybrid: a reduction by more than $80 \%$ of the greenhouse gases emissions compared to gasoline. Journal of Natural Gas Science and Engineering, Vol. 3, Issue 5, October 2011, p. 617-624.

[10] Checkel D., Dhaliwal B.: Tailpipe Emissions Comparison Between Propane and Natural Gas Forkfits, CEC/ SAE International Spring Fuels \& Lubricants Meeting, 2000, Paper No. 2000-01-1865.

[11] Commission of the European Communities: Communication from the Commission to the European parliament, the Council, the Economic and Social Committee and the Committee of the Regions on alternative fuels for road transportation and on a set of measures to promote the use of biofuels. COM (2001) 547 final, Brussels, 7.11.2001.

[12] Directive 2003/30/EC of the European Parliament and of the Council of 8 May 2003 on the promotion of the use of biofuels or other renewable fuels for transport. Official Journal of the European Union, L 123/42, 17.5.2003.

[13] Council Directive 2003/96/EC of 27 October 2003 restructuring the Community framework for the taxation of energy

Piotr Bielaczyc, DEng. - head of the Engine Research Department, BOSMAL Automotive Research and Development Institute Ltd in Bielsko-Biała.

Dr inż. Piotr Bielaczyc - kierownik Zakładu Badań Silników, Instytut Badań i Rozwoju Motoryzacji BOSMAL Sp. z o.o., Bielsko-Biała.

e-mail: piotr.bielaczyc@bosmal.com.pl products and electricity. Official Journal of the European Union L 283/51, 31.10.2003.

[14] Regulation (EC) No 715/2007 of the European Parliament and of the Council of 20 June 2007 on type approval of motor vehicles with respect to emissions from light passenger and commercial vehicles (Euro 5 and Euro 6) and on access to vehicle repair and maintenance information. Official Journal of the European Union L 171/1, 29.6.2007, Commission Regulation (EC) No 692/2008 of 18 July 2008 implementing and amending Regulation (EC) No 715/2007 Official Journal of the European Union L 199/1, 28.7.2008, Commission Regulation (EU) No 566/2011 of 8 June 2011 amending Regulation (EC) No 715/2007 of the European Parliament and of the Council and Commission Regulation (EC) No 692/2008, Official Journal of the European Union L 158/1, 16.6.2011, Commission Regulation (EU) No 459/2012 of 29 May 2012 amending Regulation (EC) No 715/2007 of the European Parliament and of the Council and Commission Regulation (EC) No 692/2008 as regards emissions from light passenger and commercial vehicles (Euro 6), Official Journal of the European Union L 142/16, 1.6.2012.

[15] Forster P., Bauerle P., Kroger K., Langer W., Thurso J.: Erdgas Bifuel-Motronic fur zukukftsorientierte CNG-Fahrzeugkonzepte. 13. Aachener Koloquium Fahrzeug - und Motorentechnik 2004. Proceedings. Aachen, Germany 2004.

[16] Karavalakis G., Durbin T., Villela M., Miller W.: Air pollutant emissions of light duty vehicles operating on various natural gas compositions. Journal of Natural Gas Science and Engineering, Vol. 4, January 2012, p. 8-16.

[17] Kinnunen T., Jahkola O., Del Re S., Moreno A., Kallinen K.: Catalytic Solutions for Emission Control of Natural Gas Vehicles. ECOCAT (not published).

[18] Semin R.A.B.: A Technical Review of Compressed Natural Gas as an Automotive Fuel for Internal Combustion Engines. American J. of Engineering and Applied Sciences 1 (4): $302-$ 311, 2008, ISSN 1941-7020.

[19] Smyth G., Lippert A.M.: The Drive for Energy Diversity and Sustainability: The Impact on Transportation Fuels and Propulsion System Portfolios. 28th International Vienna Motorsymposium 2007.

[20] Suga T., Muraishi T., Brachmann T., Yatabe F.: Potential of Natural Gas Vehicle as EEV. SAE Technical Paper 2000-01-1863.

[21] Szczotka A., Bielaczyc P., Woodburn J.: The evolution of automotive fuels and fuel test methods in response to emissions and GHG legislation. 2nd International Exhaust Emissions Symposium. Symposium Proceedings on CDRom, 26/27 May 2011, ISBN 978-83-931383-1-9.

[22] Warnecke W., Wilbrand K., Scholey H.: The Drive for Energy Independence in the Next Decades - Fuels for the Future. 28th International Vienna Motor Symposium 2007.

[23] Zhang C-H, Xie Y-L, Wang F-S, Ma Z-Y, Qi D-H, Qiu Z-W: Emission comparison of light-duty in-use flexible-fuel vehicles fuelled with gasoline and compressed natural gas based on the ECE 15 driving cycle. Proc. IMechE Vol. 225 Part D: Journal of Automobile Engineering 2011 255:90.

Andrzej Szczotka, DEng. - doctor in Engine Research Department at the BOSMAL Automotive Research \& Development Institute Ltd in Bielsko-Biała.

Dr inż. Andrzej Szczotka - adiunkt w Zakładzie Badań Silników Instytut Badań i Rozwoju Motoryzacji BOSMAL Sp. z o.o., Bielsko-Biała.

e-mail: andrzej.szczotka@bosmal.com.pl 